\title{
Face masks to prevent community transmission of viral respiratory infections: A rapid evidence review using Bayesian analysis
}

\author{
Olga Perski ${ }^{1}$, David Simons ${ }^{2}$, Robert West ${ }^{1}$, Susan Michie ${ }^{1}$ \\ 1 University College London, University of London \\ 2 Royal Veterinary College, RVC
}

\begin{abstract}
Background: Face masks have been proposed as an important way of reducing transmission of viral respiratory infections, including SARS-CoV-2.
\end{abstract}

Objective: To assess the likelihood that wearing face masks in community settings reduces transmission of viral respiratory infections.

Methods: We conducted a rapid evidence review and used a Bayesian statistical approach to analysing experimental and observational studies conducted in community-dwelling children and adults that assessed the effectiveness of face mask wearing (vs. no face masks) on self-reported, laboratory-confirmed, or clinically diagnosed viral respiratory infections.

Results: Eleven RCTs and 10 observational studies met the inclusion criteria. The calculation of Bayes factors and cumulative posterior odds from the RCTs showed a moderate likelihood of a small effect of wearing surgical face masks in community settings in reducing self-reported influenza-like illness (ILI) (cumulative posterior odds = 3.61). However, the risk of reporting bias was high and evidence of reduction of clinically- or laboratory-confirmed infection was equivocal (cumulative posterior odds = 1.07 and 1.22 , respectively). Observational studies yielded evidence of a negative association between face mask wearing and ILI but with high risk of confounding and reporting bias.

Conclusions: Available evidence from RCTs is equivocal as to whether or not wearing face masks in community settings results in a reduction in clinically- or laboratory- 
confirmed viral respiratory infections. No relevant studies concerned SARS-CoV-2 or were undertaken in community settings in the UK.

\section{Introduction}

On March 11 2020, the global outbreak of the respiratory virus SARS-CoV-2, which causes COVID-19 (1), was declared a pandemic by the World Health Organisation (2). The primary route into the body for respiratory viruses such as SARS-CoV-2 is through the nose, eyes and mouth (the ' $T$-Zone') (3). Multipronged approaches involving both pharmacological (e.g. vaccination) and behavioural measures (e.g. hand washing, social distancing) are required to bring the reproductive number below 1 during respiratory virus epidemics (4-7). In public health interventions where certainty cannot be assured, it is often necessary to judge the benefits of interventions on their likelihood of benefit versus harm. This paper reports a rapid evidence review of studies evaluating the wearing of face masks in community settings on the likelihood of their leading to a reduction in the transmission of viral respiratory infections.

SARS-CoV-2 is spread through airborne droplets, and possibly in some cases aerosol, containing virions (8). Face masks of various types (e.g. surgical masks) filter droplets containing virus. However, they may not reduce transmission of the virus in community settings if they are not used correctly and may even increase transmission if they act as fomites or prompt other behaviours that transmit the virus such as face touching. For example, a face mask that has been worn for several hours becomes moist and acts as a potential source of contamination. Studies show that people touch their faces 15-23 times per hour on average $(9,10)$, and this may mean that eyes and contaminated face masks are touched, spreading the virus. Several reviews have been undertaken on whether wearing face masks confers net benefit or harm (11-19). This rapid review aims to draw together the key evidence to date to try to establish the most comprehensive picture available. Given that policy has to be made on the basis of the likelihood of benefits versus harms rather than necessarily a high degree of confidence that a given policy will have the desired effect, it is important to focus on this likelihood. Therefore, this review includes the use of a Bayesian analysis to calculate cumulative posterior odds of the benefit of face mask wearing. It also widens the scope to consider issues such as adherence and adverse unintended consequences. We aimed to address the following research questions: 
transmission of viral respiratory infections?

2. What is the quality of the evidence on this?

3. What is the level of adherence to face mask wearing?

4. Are there adverse unintended consequences of face mask wearing?

\section{Method}

\section{Study design}

The study protocol was pre-registered on the Open Science Framework (www.osf.io/bwcxp) and McMaster University's list of COVID-19 Rapid Evidence Reviews (https://www.nccmt.ca/knowledge-repositories/covid-19-evidence-reviews). We adopted acknowledged best practice for rapid evidence reviews (20). This involved limiting the search to published literature, having one reviewer extract data and another verify and presenting results as a narrative summary $(21,22)$.

\section{Eligibility criteria}

Studies were included if they:

i. Were primary research studies using experimental (e.g. randomised controlled trial), quasi-experimental (e.g. pre- and post-test) and observational (e.g. case-control) study designs;

ii. Were conducted under free-living (as opposed to laboratory) conditions;

iii. Included a comparator (i.e. no face mask wearing);

iv. Were published in a peer-reviewed journal;

v. Were written in English;

vi. Involved as participants community-dwelling children and adults;

vii. Involved as intervention the wearing of commercial or hand-made face masks for preventing transmission of respiratory viruses;

viii. Recorded as outcome clinically or biochemically confirmed respiratory virus infections or self-reported symptoms consistent with respiratory virus infections such as influenza, respiratory syncytial virus, the common cold or SARS-CoV-2

Studies were excluded if they:

i. Involved as participants healthcare workers in healthcare settings 


\section{Search strategy}

We identified articles through screening the reference lists of 10 recent literature reviews of non-pharmacological interventions to prevent transmission of respiratory viruses identified by the review team (11-19).

\section{Selection of studies}

Two reviewers (OP, DS) independently screened titles, abstracts and full texts ag ainst the eligibility criteria.

\section{Data extraction}

Data were extracted by one reviewer and verified by a second on: i) author (year), ii) pathogen/disease studied, iii) study design, iv) setting, v) population, vi) sample size, vii) type of face masks used, viii) intervention to improve adherence to face masks, ix) any adjunct intervention (e.g. hand sanitiser), x) predictors of effectiveness (e.g. perceived susceptibility), xi) adherence to face mask wearing, xii) reported proportion of sample with confirmed respiratory virus infection or self-reported symptoms of infection, and xiii) adverse unintended consequences (e.g. reduction in hand washing or other personal protective behaviours).

\section{Evidence synthesis}

Results from individual comparisons and outcomes in individual studies were tabulated in terms of adjusted odds ratios and $95 \%$ confidence intervals with the control group as the reference.

Following inspection of the results, it was decided to undertake Bayesian analyses to quantify the likelihood that face masks were effective. This involved calculating Bayes factors for each comparison and each outcome in each study, and then combining these Bayes factors to calculate cumulative posterior odds of a reduction in respiratory viral infections (23). Bayes factors represent the ratio of the likelihood that a given hypothesis $(\mathrm{H} 1)$ is true versus another hypothesis $(\mathrm{H} 0)$. In this case, $\mathrm{H} 0$ was that there was no difference between intervention and control conditions. Two different $\mathrm{H} 1 \mathrm{~s}$ were tested: 1) a small effect of a reduction of up to $10 \%$ in the odds of infection (adjusted odds ratio 
of 0.90 ), and 2) a large effect of up to a 50\% reduction in the odds of infection (adjusted odds ratio of 0.50$)$. $\mathrm{H} 1 \mathrm{~s}$ were specified using a half-normal distribution starting on 0 with a standard deviation of the expected effects size (i.e. $10 \%$ or $50 \%$ ) (24). Bayes factors $\geq 3$ can be interpreted as substantial evidence for $\mathrm{H} 1$ versus $\mathrm{H} 0$. Bayes factors of $\leq 1 / 3$ can be interpreted as evidence for $\mathrm{H} 0$ versus $\mathrm{H} 1$. Data yielding Bayes factors between $1 / 3$ and 3 can be considered equivocal (23). Cumulative posterior odds were calculated for comparable studies (i.e. those with similar interventions and outcomes) by multiplying the Bayes factor together (23).

\section{Quality appraisal}

Two reviewers (OP, DS) used the GRADE (Grading of Recommendations, Assessment, Development and Evaluations) framework (25) to appraise the quality (low, moderate, high) of included studies.

\section{Results}

\section{Study description}

A total of 486 records were identified in the 10 literature reviews, 29 full texts were assessed, 21 of which met the inclusion criteria (see Figure 1).

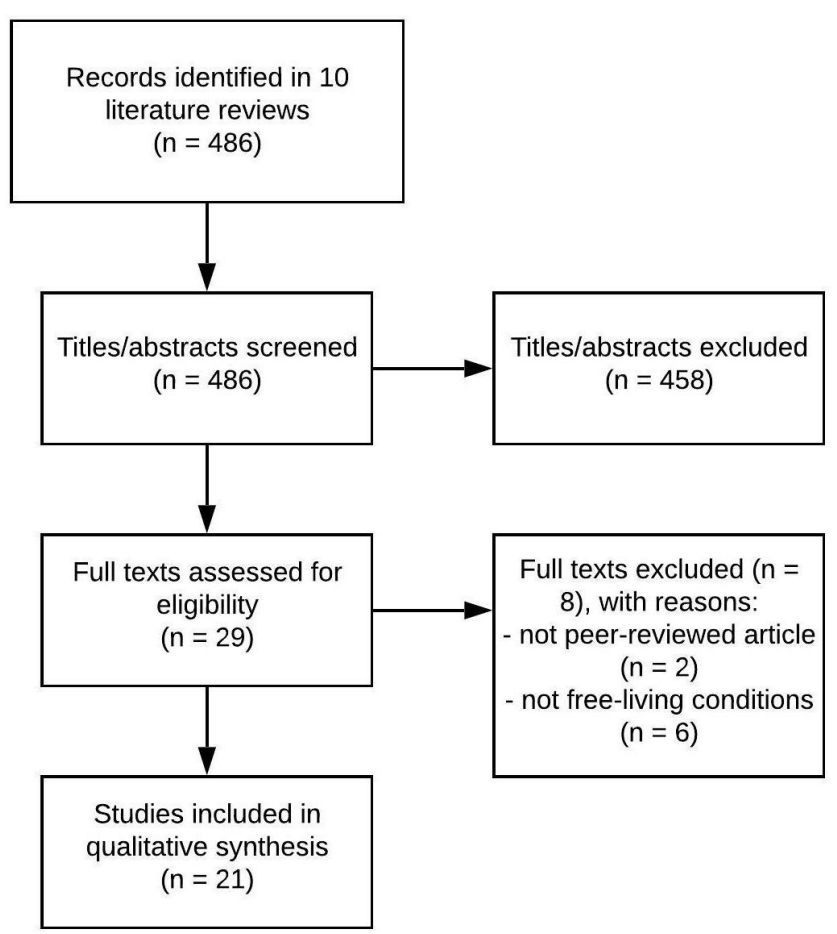


Figure 1. PRISMA flow diagram of included studies.

\section{Study setting}

The included studies were conducted in Saudi Arabia (26-32), China (including Hong Kong) (33-36), US (37-39), Japan (40,41), Germany (42), France (43), Australia (44), South Korea (45) and Thailand (46). No studies were found that were conducted in the UK.

Seven studies were conducted in households of index cases identified in primary or secondary care $(33,35,36,43,44,46)$. Seven studies, all of which were conducted in Saudi Arabia, included participants on Hajj pilg rimage who were temporarily resident in communal tents or caravans (26-32). Five studies were conducted in the wider community, with participants recruited from universities $(40)$, schools $(41,45)$ and households $(34,39)$. Two studies were conducted in university halls of residence $(37,38)$.

Three studies were conducted during the 2009/2010 H1N1 epidemic $(31,42,45)$ and one study was conducted during the 2002/2003 SARS epidemic (34); the remaining studies were conducted during non-epidemic conditions. No studies were found that were conducted within the SARS-CoV-2 pandemic (see Table 1).

Table 1. Characteristics of included studies $(n=21)$.

\begin{tabular}{|c|c|c|c|c|}
\hline Lead author (year) & Country & Disease & Study design & Sample size \\
\hline Aiello (2010) & US & Influenza-like illness & Cluster RCT & 1297 \\
\hline Aiello (2012) & US & Influenza-like illness & Cluster RCT & 1178 \\
\hline Al-Jasser (2012) & Saudi Arabia & Respiratory illness & Prospective cohort & 1507 \\
\hline Balaban (2012) & Saudi Arabia & Respiratory illness & Prospective cohort & 186 \\
\hline Barasheed (2014) & Saudi Arabia & Influenza-like illness & Pilot RCT & 164 \\
\hline Canini (2010) & France & Influenza-like illness & Cluster RCT & 105 index cases; 306 contacts \\
\hline Choudhry (2006) & Saudi Arabia & Respiratory illness & Prospective cohort & 1130 \\
\hline Cowling (2008) & Hong Kong & Influenza-like illness & Cluster RCT & 122 index cases, 350 contacts \\
\hline Cowling (2009) & Hong Kong & Influenza-like illness & Cluster RCT & 407 index cases, 876 contacts \\
\hline Deris (2010) & Saudi Arabia & Influenza-like illness & Cross-sectional & 387 \\
\hline Emamian (2013) & Saudi Arabia & Respiratory illness & Nested case-control & 338 \\
\hline Hashim (2016) & Saudi Arabia & Respiratory illness & Cross-sectional & 468 \\
\hline Kim (2012) & South Korea & H1N1 & Cross-sectional & 7488 \\
\hline Larson (2010) & US & Influenza-like illness & Cluster RCT & 2788 \\
\hline Maclntyre (2009) & Australia & Influenza-like illness & Cluster RCT & 145 index cases, 286 contacts \\
\hline Maclntyre (2016) & China & Influenza-like illness & Cluster RCT & 245 index cases, 597 contacts \\
\hline Shin (2018) & Japan & Common cold & Prospective cohort & 265 \\
\hline Simmerman (2011) & Thailand & Influenza-like illness & Cluster RCT & 465 index cases, 586 contacts \\
\hline Suess (2012) & Germany & Influenza-like illness & Cluster RCT & 84 index cases, 218 contacts \\
\hline Uchida (2017) & Japan & Influenza-like illness & Prospective cohort & 10,524 \\
\hline Wu (2004) & China & SARS & Case-control & 94 cases, 281 controls \\
\hline
\end{tabular}




\section{Study population}

The majority of studies were conducted in adults, aged $16+$ years $(26,27,40,44,28$ $33,37,38)$. Seven studies were conducted in children and adults $(34-36,39,42,43,46)$. T wo studies were conducted in children only $(41,45)$. Seven studies with participants on $\mathrm{Haj}$ pilgrimage to Saudi Arabia included travelers from countries including Malaysia, Australia and the US (26-32).

\section{Type and purpose of face mask use}

Twelve studies reported outcomes related to the use of surgical masks $(26,32,44,46,33,35-39,42,43)$. Nine studies did not record the type of mask used (27$31,34,40,41,45)$.

Ten studies employed observational designs and did not mandate who (e.g. index cases, contacts) was wearing the mask $(27-32,34,40,41,45)$. Eleven studies employed cluster RCT designs, of which five studies instructed index patients and their contacts to use masks $(26,35,36,42,46)$, three studies instructed asymptomatic participants to use masks (37-39), two studies instructed index cases to use masks $(33,43)$ and one study instructed contacts of index cases to use masks (44).

\section{Interventions to improve adherence to and safe disposal of face masks}

No intervention to improve adherence to, or safe disposal of, mask use was provided to participants in the 10 observational studies $(27-31,34,40,41,45)$. In the 11 RCTs, brief education was provided on the appropriate use of face masks and how to correctly take them on and off $(26,33,46,35-39,42-44)$. Eight of the 11 RCTs provided adjunct interventions in the form of hand sanitizer $(26,35-39,42)$ or instructions to wash hands (46).

\section{Outcomes}

Adherence to mask use

Studies operationalised self-reported adherence as hours/day of mask use 
$(26,37,38,43,46)$, the proportion of participants reporting mask use always or most of the time (vs. sometimes or never) $(27,29,34,35,42)$, the proportion of participants reporting mask use as instructed (44) and the proportion of participants who reported mask use within 48 hours of symptom onset (39). Of studies explicitly commenting on the level of adherence to mask use, three study authors stated that adherence was 'good' $(26,42,43)$ and three stated that it was 'poor' $(35,39,44)$. Six studies did not report adherence to mask use $(28,31,33,40,41,45)$.

\section{Effectiveness of mask use}

RCTS

The outcomes of included studies are reported in Table 2. One study found lower rates of self-reported symptoms of influenza-like illness (ILI) in the intervention compared with the control arm; however, in secondary analyses with laboratory-confirmed ILI, the rate of infection was less in the control arm than the intervention arm (26). Ten studies, two of which were pilot studies, found no statistically significant reduction in the rate of laboratory-confirmed or self-reported symptoms of ILI with face mask use in their primary analyses (33,35-39,42-44,46). In post-hoc (underpowered) analyses, however, significant reductions in rates of ILI were reported in six studies. Two studies found reduced rates of ILI in weeks 3-6 of the study period (totaling 6 weeks) $(37,38)$. One study found significantly reduced odds of a household contact developing laboratoryconfirmed ILI when the analysis was confined to participants who were allocated to the intervention or control arms within the first 36 hours of symptom onset in the index patient (36). One study found a significant reduction in the number of viral symptom episodes in a multivariable analysis following adjustment for age of the index case, education level of the caretaker and home crowding index (but not in a univariable analysis) (39). Two studies found a significant reduction in the rate of ILI in household contacts when, in a post-hoc analysis, they restricted the analysis to participants who received the face masks within 36 hours or two days of index case diagnosis or symptom onset, respectively $(42,44)$. One study found a significant reduction in respiratory infections when restricting the analysis to the less stringent end-point of clinical respiratory illness (as compared with laboratory-confirmed infections or ILI) (33). The calculation of Bayes factors and cumulative posterior odds indicated that data showed a moderate likelihood of a small effect for the wearing of face masks on self-reported symptoms but evidence on clinically- or laboratory-confirmed ILI was equivocal (see Table 3). 
Six observational studies found a significant reduction in self-reported respiratory virus symptoms in individuals who reported the use of face masks (as compared with no face mask use) $(27,29,34,40,41,45)$. Four studies found no significant reduction in respiratory virus symptoms in individuals who reported the use of face masks (28,30-32). The calculation of Bayes factors and cumulative posterior odds indicated that data provided evidence for a large effect of the wearing of face masks on self-reported and clinicallyconfirmed ILI (see Table 3).

Table 2. Outcomes of included studies.

\begin{tabular}{|c|c|c|c|c|}
\hline $\begin{array}{l}\text { Lead author } \\
\text { (year) }\end{array}$ & $\begin{array}{l}\text { Sample } \\
\text { size }^{1}\end{array}$ & $\begin{array}{l}\text { Adjusted odds ratio }(95 \% \\
\text { Cl) }\end{array}$ & Intervention arm(s) & Outcome(s) \\
\hline \multicolumn{5}{|l|}{ RCTs } \\
\hline Aiello (2010) & 1042 & $\begin{array}{l}1.00 \\
0.90(0.77-1.05)^{2} \\
0.87(0.73-1.02)^{2}\end{array}$ & $\begin{array}{l}\text { Education on hand hygiene } \\
\text { Face mask } \\
\text { Face mask plus hand hygiene }\end{array}$ & Self-reported ILI \\
\hline Aiello (2012) & 828 & $\begin{array}{l}1.00 \\
1.10(0.88-1.38)^{2} \\
0.78(0.57-1.08)^{2}\end{array}$ & $\begin{array}{l}\text { No intervention } \\
\text { Face mask } \\
\text { Face mask plus hand hygiene }\end{array}$ & Self-reported ILI \\
\hline Barasheed (2014) & 164 & $\begin{array}{l}1.00 \\
0.39(0.16-0.96)^{* 3}\end{array}$ & $\begin{array}{l}\text { No intervention } \\
\text { Face mask }\end{array}$ & Self-reported ILI \\
\hline Canini (2010) & 296 & $\begin{array}{l}1.00 \\
0.95(0.44-2.05)\end{array}$ & $\begin{array}{l}\text { No intervention } \\
\text { Face mask }\end{array}$ & Self-reported ILI \\
\hline Cowling (2008) & 262 & $\begin{array}{l}1.00 \\
1.16(0.31-4.34)\end{array}$ & $\begin{array}{l}\text { Education on healthy lifestyle } \\
\text { Face mask }\end{array}$ & Laboratory confirmed influenza \\
\hline Cowling (2009) & 537 & $\begin{array}{l}1.00 \\
0.77(0.38-1.55)\end{array}$ & $\begin{array}{l}\text { Education on healthy lifestyle } \\
\text { Face mask plus hand hygiene }\end{array}$ & Laboratory confirmed influenza \\
\hline Larson (2010) & 2788 & 1.00 & Education on infection control and prevention & $\begin{array}{l}\text { Self-reported respiratory infection, ILI and laboratory confirmed } \\
\text { influenza }\end{array}$ \\
\hline Maclntyre (2009) & 286 & $\begin{array}{l}0.82(0.70-0.97) \\
1.00 \\
1.11(0.64-1.91) \\
2.51(0.74-8.5)\end{array}$ & $\begin{array}{l}\text { Face mask plus hand hygiene } \\
\text { No intervention } \\
\text { Face mask } \\
\text { Face mask }\end{array}$ & $\begin{array}{l}\text { Self-reported ILI' } \\
\text { Self-reported ILI' } \\
\text { Laboratory confirmed influenza }\end{array}$ \\
\hline Maclntyre (2016) & 597 & $\begin{array}{l}1.00 \\
0.65(0.18-2.29)^{7} \\
0.32(0.03-3.11)^{7} \\
0.97(0.06-15.5)^{7}\end{array}$ & $\begin{array}{l}\text { No intervention } \\
\text { Face mask } \\
\text { Face mask } \\
\text { Face mask }\end{array}$ & $\begin{array}{l}\text { Clinical respiratory illness }{ }^{6} \\
\text { Clinical respiratory illness }^{6} \\
\text { Self-reported ILI6 } \\
\text { Laboratory confirmed respiratory infection }\end{array}$ \\
\hline $\begin{array}{l}\text { Simmerman } \\
\text { (2011) }\end{array}$ & 885 & $\begin{array}{l}1.00 \\
1.16(0.74-1.82)^{3}\end{array}$ & $\begin{array}{l}\text { No intervention } \\
\text { Face mask plus hand hygiene }\end{array}$ & Laboratory confirmed influenza \\
\hline \multirow[t]{2}{*}{ Suess (2012) } & 216 & 1.00 & Education on infection prevention & Laboratory confirmed influenza \\
\hline & & $0.50(0.21-1.19)$ & $\begin{array}{l}\text { Combined arms (face mask and face mask plus hand } \\
\text { hygiene) }\end{array}$ & \\
\hline
\end{tabular}

Table 2 cont. 


\begin{tabular}{|c|c|c|c|c|}
\hline \multicolumn{5}{|l|}{ Observational } \\
\hline Al-Jasser (2012) & 1507 & $\begin{array}{l}1.00 \\
0.85(0.72-1.00)^{8} \\
0.83(0.70-0.97)^{8}\end{array}$ & $\begin{array}{l}\text { Face mask (never) } \\
\text { Face mask (sometimes) } \\
\text { Face mask (most of the time) }\end{array}$ & Self-reported respiratory infection \\
\hline Balaban (2012) & 143 & $\begin{array}{l}1.00 \\
1.42(0.70-2.88)\end{array}$ & $\begin{array}{l}\text { No face mask } \\
\text { Face mask }\end{array}$ & Self-reported respiratory illness \\
\hline Choudhry (2006) & 1027 & $\begin{array}{l}1.00 \\
0.48(0.35-0.66)^{8} \\
0.25(0.19-0.32)^{8}\end{array}$ & $\begin{array}{l}\text { Face mask (never) } \\
\text { Face mask (sometimes) } \\
\text { Face mask (most of the time) }\end{array}$ & Self-reported respiratory infection \\
\hline Deris (2010) & 394 & $\begin{array}{l}1.00 \\
1.57(0.98-2.52)^{3}\end{array}$ & $\begin{array}{l}\text { No face mask } \\
\text { Face mask }\end{array}$ & Self-reported ILI \\
\hline Emamian (2013) & 95 & $\begin{array}{l}1.00 \\
1.56(0.56-4.35)^{3}\end{array}$ & $\begin{array}{l}\text { No face mask } \\
\text { Face mask }\end{array}$ & Clinically reported respiratory infection \\
\hline Hashim (2016) & 468 & $\begin{array}{l}1.00 \\
1.65(0.79-3.47)\end{array}$ & $\begin{array}{l}\text { No face mask } \\
\text { Face mask }\end{array}$ & Self-reported respiratory illness \\
\hline $\operatorname{Kim}(2012)$ & 7449 & $\begin{array}{l}1.00 \\
1.02(0.83-1.25)^{3} \\
0.51(0.30-0.88)^{3}\end{array}$ & $\begin{array}{l}\text { No face mask } \\
\text { Face mask (irregular) } \\
\text { Face mask (continuous) }\end{array}$ & Laboratory confirmed influenza \\
\hline Shin (2018) & 172 & $\begin{array}{l}1.00 \\
0.79(0.41-1.54)^{3}\end{array}$ & $\begin{array}{l}\text { No face mask } \\
\text { Face mask }\end{array}$ & Self-reported viral respiratory symptoms \\
\hline Uchida (2017) & 10,524 & $\begin{array}{l}1.00 \\
0.86(0.78-0.95)\end{array}$ & $\begin{array}{l}\text { No face mask } \\
\text { Face mask }\end{array}$ & Clinically diagnosed influenza \\
\hline Wu (2004) & 100 & $\begin{array}{l}1.00 \\
0.50(0.20-0.90)^{3} \\
0.30(0.20-0.60)^{3}\end{array}$ & $\begin{array}{l}\text { No face mask } \\
\text { Face mask (sometimes) } \\
\text { Face mask (always) }\end{array}$ & Self-reported SARS-like symptoms \\
\hline
\end{tabular}

${ }^{1}$ Sample size analysed; ${ }^{2}$ Cumulative rate ratio; ${ }^{3}$ Unadjusted odds ratio; ${ }^{4}$ Composite end point; ${ }^{5}$ Not surgical mask (e.g. towel, veil); ${ }^{6}$ Listed as primary outcomes; ${ }^{7}$ Unadjusted rate ratio; ${ }^{8}$ Unadjusted relative risk; $"$ Point estimate and confidence intervals derived by the review team from raw percentages; Numbers in bold face indicate statistical significance at $\mathrm{p}<.05$

Table 3. Bayes factors and cumulative posterior odds for postulated small and large

effects of face mask wearing in community settings.

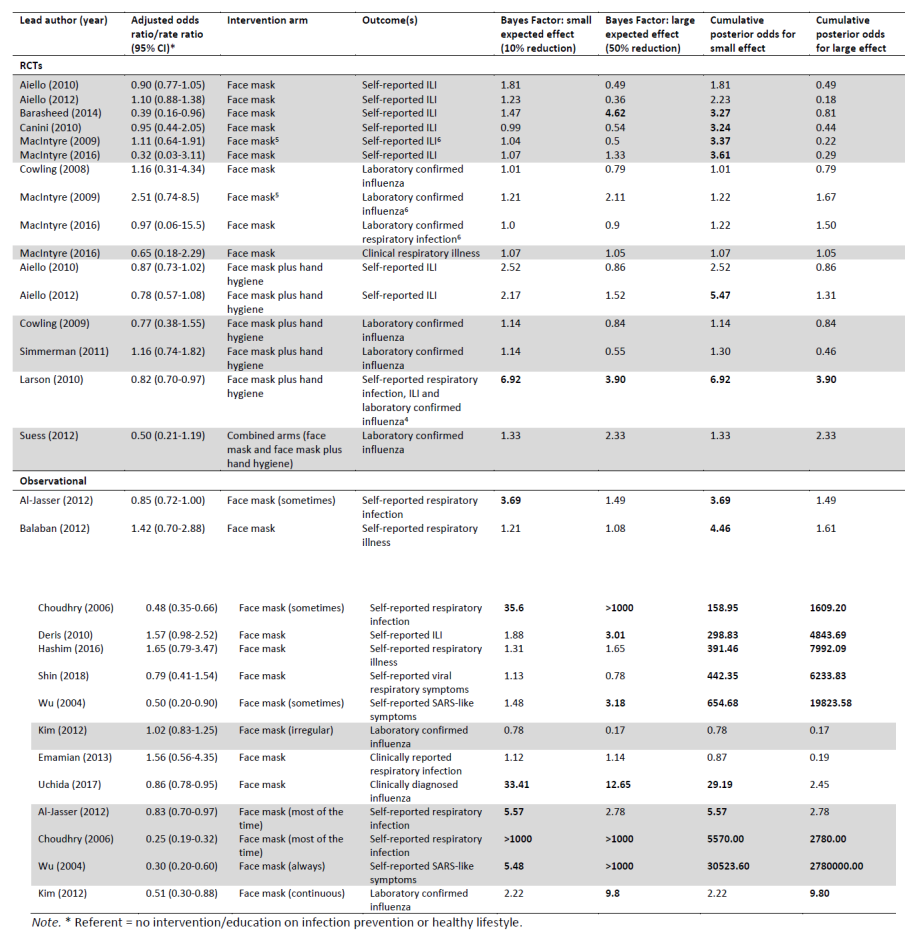

\section{Predictors of clinical outcomes}

Four studies assessed whether self-reported adherence to mask use was a predictor of clinical outcomes, three of which observed a positive association $(26,34,44)$ and one did 
not (43). Two studies found reduced rates of infection when participants had been allocated to wear face masks within 36 hours of symptom onset $(36,42)$. One study found that when the number of protective behaviours (e.g. hand washing, face mask use) was considered as a continuous variable, those eng aging in a greater number of protective behaviours experienced shorter duration of respiratory illness (31).

\section{Adverse unintended consequences}

The majority of included studies did not report on whether there were unintended consequences. Two studies found that $50-75 \%$ of participants in the face mask arm reported pain/discomfort with mask use $(43,44)$. One study found that those allocated to the face mask arm (as compared with those allocated to the face mask plus hand sanitiser or control arms) reported significantly less use of hand sanitiser (38). Four studies reported no significant differences in hand hygiene across study arms $(35,36,39,46)$.

\section{Quality appraisal}

The quality ratings for each study are reported in Table 4.

\section{Study limitations}

Participant blinding to group allocation was not possible. Some studies reported contamination as participants in control arms decided to use face masks of their own accord $(26,33,35,36)$. Use of self-reported (as opposed to laboratory-confirmed) respiratory virus symptoms or illness was commonplace. Overall, adherence to face mask use was poorly recorded.

\section{Inconsistency of results}

Only one of the 11 higher-quality studies employing RCT designs found a significantly reduced rate of ILI in their primary analyses. Both of the two higher-quality observational studies found a significantly reduced rate of clinically- or laboratory-confirmed ILI $(41,45)$. Hence, the results are inconsistent across study designs and outcome assessments, with those employing more robust designs finding a non-significant effect of face mask use. 


\section{Indirectness of evidence}

Only four of the included studies were conducted during an ongoing epidemic $(31,34,42,45)$ and none was conducted during the SARS-CoV-2 pandemic. Only one of the 11 RCT s assessed transmission in the wider community (39); the remaining studies assessed viral spread to contacts who shared accommodation. A key concern during respiratory virus pandemics is transmission outside the household of index patients.

\section{Imprecision}

The RCT that found a significant effect of face mask use did not provide a confidence interval for the point estimate (26). One of the two higher-quality observational studies reported a narrow confidence interval, likely due to the large sample size (41). The remaining five observational studies with positive results reported wide confidence intervals $(27,29,34,40,45)$, thus indicating poor precision of the effect of face mask use.

\section{$\underline{\text { Reporting bias }}$}

Most analyses were not pre-registered, opening the possibility (especially in secondary analyses) of 'cherry picking' of findings.

Table 4. GRADE quality ratings for the included studies. 


\begin{tabular}{|c|c|c|c|c|c|}
\hline $\begin{array}{l}\text { Lead author } \\
\text { (year) }\end{array}$ & Study limitations & Indirectness of evidence & Imprecision & Reporting bias & $\begin{array}{l}\text { GRADE } \\
\text { rating }\end{array}$ \\
\hline Aiello (2010) & $\begin{array}{l}\text { Self-reported ILI; } \\
\text { Pilot study }\end{array}$ & $\begin{array}{l}\text { Non-epidemic } \\
\text { conditions }\end{array}$ & $\begin{array}{l}\text { Wide confidence } \\
\text { interval reported }\end{array}$ & $\begin{array}{l}\text { Potential 'cherry } \\
\text { picking' }\end{array}$ & Low \\
\hline Aiello (2012) & Self-reported ILI & $\begin{array}{l}\text { Non-epidemic } \\
\text { conditions }\end{array}$ & & $\begin{array}{l}\text { Potential 'cherry } \\
\text { picking' }\end{array}$ & Moderate \\
\hline $\begin{array}{l}\text { Al-Jasser } \\
\text { (2012) }\end{array}$ & $\begin{array}{l}\text { Not RCT; Self- } \\
\text { reported ILI }\end{array}$ & $\begin{array}{l}\text { Non-epidemic } \\
\text { conditions }\end{array}$ & $\begin{array}{l}\text { Wide confidence } \\
\text { interval reported }\end{array}$ & & Low \\
\hline Balaban (2012) & $\begin{array}{l}\text { Not RCT; Self- } \\
\text { reported ILI; } \\
\text { Adherence not } \\
\text { reported }\end{array}$ & Epidemic conditions & $\begin{array}{l}\text { Wide confidence } \\
\text { interval reported }\end{array}$ & & Low \\
\hline $\begin{array}{l}\text { Barasheed } \\
\text { (2014) }\end{array}$ & $\begin{array}{l}\text { Self-reported ILI; } \\
\text { Contamination }\end{array}$ & $\begin{array}{l}\text { Non-epidemic } \\
\text { conditions }\end{array}$ & $\begin{array}{l}\text { Confidence interval } \\
\text { not reported }\end{array}$ & & Low \\
\hline Canini (2010) & $\begin{array}{l}\text { Self-reported ILI; } \\
\text { Early termination }\end{array}$ & $\begin{array}{l}\text { Non-epidemic } \\
\text { conditions }\end{array}$ & $\begin{array}{l}\text { Wide confidence } \\
\text { interval reported }\end{array}$ & & Low \\
\hline $\begin{array}{l}\text { Choudhry } \\
(2006)\end{array}$ & $\begin{array}{l}\text { Not RCT; Self- } \\
\text { reported ILI }\end{array}$ & $\begin{array}{l}\text { Non-epidemic } \\
\text { conditions }\end{array}$ & $\begin{array}{l}\text { Wide confidence } \\
\text { interval reported }\end{array}$ & & Low \\
\hline Cowling (2008) & $\begin{array}{l}\text { Laboratory- } \\
\text { confirmed ILI; } \\
\text { Contamination; Pilot } \\
\text { study }\end{array}$ & $\begin{array}{l}\text { Non-epidemic } \\
\text { conditions }\end{array}$ & $\begin{array}{l}\text { Wide confidence } \\
\text { interval reported }\end{array}$ & & Low \\
\hline Cowling (2009) & $\begin{array}{l}\text { Laboratory- } \\
\text { confirmed ILI; } \\
\text { Contamination }\end{array}$ & $\begin{array}{l}\text { Non-epidemic } \\
\text { conditions }\end{array}$ & $\begin{array}{l}\text { Wide confidence } \\
\text { interval reported }\end{array}$ & $\begin{array}{l}\text { Potential 'cherry } \\
\text { picking' }\end{array}$ & Moderate \\
\hline Deris (2010) & $\begin{array}{l}\text { Not RCT; Self- } \\
\text { reported ILI; } \\
\text { Adherence not } \\
\text { reported }\end{array}$ & $\begin{array}{l}\text { Non-epidemic } \\
\text { conditions }\end{array}$ & $\begin{array}{l}\text { Wide confidence } \\
\text { interval reported }\end{array}$ & & Low \\
\hline $\begin{array}{l}\text { Emamian } \\
\text { (2013) }\end{array}$ & $\begin{array}{l}\text { Not RCT; Clinically } \\
\text { confirmed ILI }\end{array}$ & $\begin{array}{l}\text { Non-epidemic } \\
\text { conditions }\end{array}$ & $\begin{array}{l}\text { Wide confidence } \\
\text { interval reported }\end{array}$ & & Low \\
\hline Hashim (2016) & $\begin{array}{l}\text { Self-reported ILI; Not } \\
\text { RCT }\end{array}$ & $\begin{array}{l}\text { Non-epidemic } \\
\text { conditions }\end{array}$ & $\begin{array}{l}\text { Wide confidence } \\
\text { interval reported }\end{array}$ & & Low \\
\hline Kim (2012) & $\begin{array}{l}\text { Not RCT; Laboratory- } \\
\text { confirmed ILI; } \\
\text { Adherence not } \\
\text { reported }\end{array}$ & Epidemic conditions & $\begin{array}{l}\text { Wide confidence } \\
\text { interval reported }\end{array}$ & & Moderate \\
\hline Larson (2010) & Self-reported ILI & $\begin{array}{l}\text { Non-epidemic } \\
\text { conditions; masks not } \\
\text { only provided to } \\
\text { households with an } \\
\text { index case }\end{array}$ & $\begin{array}{l}\text { Wide confidence } \\
\text { interval reported }\end{array}$ & $\begin{array}{l}\text { Potential 'cherry } \\
\text { picking' }\end{array}$ & Moderate \\
\hline $\begin{array}{l}\text { Maclntyre } \\
\text { (2009) }\end{array}$ & Self-reported ILI & $\begin{array}{l}\text { Non-epidemic } \\
\text { conditions }\end{array}$ & $\begin{array}{l}\text { Wide confidence } \\
\text { interval reported }\end{array}$ & $\begin{array}{l}\text { Potential 'cherry } \\
\text { picking' }\end{array}$ & Moderate \\
\hline $\begin{array}{l}\text { Macintyre } \\
(2016)\end{array}$ & $\begin{array}{l}\text { Self-reported ILI; } \\
\text { Contamination; } \\
\text { Adherence not } \\
\text { reported }\end{array}$ & $\begin{array}{l}\text { Non-epidemic } \\
\text { conditions }\end{array}$ & $\begin{array}{l}\text { Wide confidence } \\
\text { interval reported }\end{array}$ & $\begin{array}{l}\text { Potential 'cherry } \\
\text { picking' }\end{array}$ & Moderate \\
\hline Shin (2018) & $\begin{array}{l}\text { Not RCT; Adherence } \\
\text { not reported }\end{array}$ & $\begin{array}{l}\text { Non-epidemic } \\
\text { conditions }\end{array}$ & $\begin{array}{l}\text { Wide confidence } \\
\text { interval reported }\end{array}$ & & Low \\
\hline $\begin{array}{l}\text { Simmerman } \\
\text { (2011) }\end{array}$ & $\begin{array}{l}\text { Laboratory- } \\
\text { confirmed ILI }\end{array}$ & $\begin{array}{l}\text { Non-epidemic } \\
\text { conditions }\end{array}$ & $\begin{array}{l}\text { Wide confidence } \\
\text { interval reported }\end{array}$ & & Moderate \\
\hline Suess (2012) & $\begin{array}{l}\text { Laboratory- } \\
\text { confirmed ILI }\end{array}$ & Epidemic conditions & $\begin{array}{l}\text { Wide confidence } \\
\text { interval reported }\end{array}$ & $\begin{array}{l}\text { Potential 'cherry } \\
\text { picking' }\end{array}$ & Moderate \\
\hline Uchida (2017) & $\begin{array}{l}\text { Not RCT; Adherence } \\
\text { not reported }\end{array}$ & $\begin{array}{l}\text { Non-epidemic } \\
\text { conditions }\end{array}$ & $\begin{array}{l}\text { Narrow confidence } \\
\text { interval reported }\end{array}$ & & Moderate \\
\hline Wu (2004) & Not RCT & Epidemic conditions & $\begin{array}{l}\text { Wide confidence } \\
\text { interval reported }\end{array}$ & & Low \\
\hline
\end{tabular}

\section{Discussion}

Principal findings

This rapid review synthesised evidence from RCTs and observational studies on the effectiveness of face mask use to reduce transmission of respiratory viruses in community settings. This review widened the scope of available reviews on this topic to consider issues such as adherence and adverse unintended consequences of face mask wearing. One out of 11 RCTs and six out of 10 observational studies found a reduction in 
the rate of self-reported or clinician diagnosed ILI in participants wearing face masks. The calculation of Bayes factors and cumulative posterior odds indicated that data from the RCT s and observational studies provided evidence of a small and large effect, respectively, of face mask wearing on self-reported ILI. Adherence and unintended consequences were rarely reported.

\section{Strengths and limitations}

An important feature of this review was the calculation of Bayes factors and cumulative posterior odds to examine the relative likelihood of there being an effect of wearing face masks versus no effect. A major limitation was that the search strategy may have missed relevant studies. Other major limitations relate to the studies themselves, including reliance on self-reported outcomes and reporting bias. In one study that included both self-reported and laboratory-confirmed infection, the former showed a benefit while the latter showed the opposite.

\section{Implications for policy and practice}

While the potentially biased self-reported outcomes from RCTs suggest a small benefit of face mask wearing, findings on clinically- and laboratory-confirmed infection remain equivocal. In addition, none of the studies concerned SARS-CoV-2 and none were conducted in the UK. All were in community settings that were different in many respects from the situation pertaining to SARS-CoV-2 in the UK. In light of this, judgements about the benefits or harms of wearing face masks will have to be made using a priori arguments rather than the data reviewed here: the scientific evidence should be considered equivocal. Such arguments should pay special attention to specific settings where the risk of infection is high and the opportunity for physical distancing is low (e.g. on crowded public transport), and to the need for education and training to maximise the potential benefits of wearing masks and mitigate the risk that they will transmit infection by acting as fomites.

\section{Future research priorities}

A standard protocol needs to be established for evaluating the benefits or harms of specific approaches to promoting face mask wearing in defined settings and populations. These protocols need to use objective measures of infection and take special precautions to minimise the risk of bias. They also need to include specific information on 
what was done to promote the appropriate use of face masks and collect data on spillover effects. Such a protocol is urgently needed for the COVID-19 pandemic but will continue to be relevant for future epidemics.

\section{Conclusions}

Evidence from RCTs is equivocal on whether face mask wearing in community settings reduces the transmission of clinically- or laboratory-confirmed viral respiratory infections. RCTs and observational studies have found an effect on self-reported symptoms, but this may be the result of reporting bias and confounding. No relevant studies concerned SARS-CoV-2 or were undertaken in community settings in the UK.

\section{Conflicts of interest}

None declared.

\section{References}

1. Li Q, Guan X, Wu P, Wang X, Zhou L, Tong Y, et al. Early Transmission Dynamics in Wuhan, China, of Novel Coronavirus-Infected Pneumonia. N EngIJ Med. 2020;1-9.

2. World Health Organisation. Rolling updates on coronavirus disease (COVID-19). 2020.

3. West R, Michie S, Rubin J, Amlôt R. Don't touch the T-Zone-how to block a key pathway to infection with SARS-CoV-2. BMJ Opinion. 2020 Apr 3;

4. Ferguson NM, Cummings DAT, Fraser C, Cajka JC, Cooley PC, Burke DS. Strategies for mitigating an influenza pandemic. Nature. 2006;442(7101):448-52.

5. Michie S, West R, Amlôt R, Rubin J. Slowing down the covid-19 outbreak: changing behaviour by understanding it. BMJ Opinion. 2020 Mar 11;

6. Michie S, West R, Amlôt R. Behavioural strategies for reducing covid-19 transmission in the general population. BMJ Opinion. 2020 Mar 3;

7. Michie S, Rubin J, Amlôt R. Behavioural science must be at the heart of the public health response to covid-19. BMJ Opinion. 2020 Feb 28;

8. World Health Organisation. Coronavirus disease 2019 (COVID-19): Situation Report - 66. 2020.

9. Nicas M, Best D. A study quantifying the hand-to-face contact rate and its potential application to predicting respiratory tract infection. J Occup Environ Hyg. 2008;5(6):347-52. 
10. Kwok YLA, Gralton J, McLaws ML. Face touching: A frequent habit that has implications for hand hygiene. Am J Infect Control [Internet]. 2015;43(2):112-4. Available from: http://dx.doi.org/10.1016/j.ajic.2014.10.015

11. Greenhalgh T, Schmid MB, Czypionka T, Bassler D, Gruer L. Face masks for the public during the covid-19 crisis. BMJ [Internet]. 2020;369:m1435. Available from: http://www.ncbi.nlm.nih.gov/pubmed/32273267

12. Xiao J, Shiu EYC, Gao H, Wong JY, Fong MW, Ryu S, et al. Nonpharmaceutical Measures for Pandemic Influenza in Nonhealthcare Settings - Personal Protective and Environmental Measures. Emerg Infect Dis. 2020;26(5).

13. Jefferson T, Jones MA, Al-Ansary L, Bawazeer GA, Beller EM, Clark J, et al. Physical interventions to interrupt or reduce the spread of respiratory viruses. Part 1 - Face masks, eye protection and person distancing: systematic review and meta-analysis. medRxiv. 2020;

14. Jefferson T, Del Mar CB, Dooley L, Ferroni E, Al-Ansary LA, Bawazeer GA, et al. Physical interventions to interrupt or reduce the spread of respiratory viruses. Cochrane Database Syst Rev. 2011;CD006207(7).

15. Howard J, Huang A, Li Z, T ufekci Z, Zdimal V, Westhuizen H Van Der. Face Masks Against COVID-19: An Evidence Review. Preprints. 2020;

16. Cowling BJ, Zhou Y, Ip DKM, Leung GM, Aiello AE. Face masks to prevent transmission of influenza virus: a systematic review. Epidemiol Infect. 2010;138(4):44956.

17. Bin-Reza F, Lopez Chavarrias V, Nicoll A, Chamberland ME. The use of masks and respirators to prevent transmission of influenza: A systematic review of the scientific evidence. Influenza Other Respi Viruses. 2012;6(4):257-67.

18. Liang M, Gao L, Cheng C, Zhou Q, Uy JP, Heiner K, et al. Efficacy of face mask in preventing respiratory virus transmission: a systematic review and meta-analysis. medRxiv. 2020;

19. Marasinghe KM. A systematic review investigating the effectiveness of face mask use in limiting the spread of COVID-19 among medically not diagnosed individuals: shedding light on current recommendations provided to individuals not medically diagnosed with COVID-19. Res Sq [Internet]. 2020; Available from: http://www.epistemonikos.org/documents/f74e1b4ee1eb3f52c7eb7d08345f1a5ba48bf $\mathrm{f} 4 \mathrm{f}$

20. World Health Organisation. Rapid reviews to strengthen health policy and systems: a practical guide. Tricco AC, Langlois E V, Straus SE, editors. 2017. 1-142 p.

21. Tricco AC, Antony J, Zarin W, Strifler L, Ghassemi M, Ivory J, et al. A scoping review of rapid review methods. BMC Med [Internet]. 2015;13:224. Available from: 
http://dx.doi.org/10.1186/s12916-015-0465-6

22. Haby MM, Chapman E, Clark R, Barreto J, Reveiz L, Lavis JN. What are the best methodologies for rapid reviews of the research evidence for evidence-informed decision making in health policy and practice: A rapid review. Heal Res Policy Syst [Internet]. 2016;14(1):1-12. Available from: http://dx.doi.org/10.1186/s12961-016-0155-7

23. Dienes Z. Bayesian versus orthodox statistics: Which side are you on? Perspect Psychol Sci. 2011;6(3):274-90.

24. Dienes Z. Online Calculator [Internet]. Available from:

http://www.lifesci.sussex.ac.uk/home/Zoltan_Dienes/inference/Bayes.htm

25. Guyatt GH, Oxman AD, Vist GE, Kunz R, Falck-Ytter Y, Alonso-Coello P, et al. GRADE: An emerging consensus on rating quality of evidence and strength of recommendations. BMJ. 2008;336:924-6.

26. Barasheed O, Almasri N, Badahdah A-M, Heron L, Taylor J, McPhee K, et al. Pilot Randomised Controlled Trial to Test Effectiveness of Facemasks in Preventing Influenzalike Illness Transmission among Australian Hajj Pilgrims in 2011. Infect Disord - Drug Targets. 2014;14(2):110-6.

27. Al-Jasser FS, Kabbash IA, AlMazroa MA, Memish ZA. Patterns of diseases and preventive measures among domestic hajis from central, Saudi Arabia. Saudi Med J. 2012;33(8):879-86.

28. Deris ZZ, Hasan H, Sulaiman SA, Wahab MSA, Naing NN, Othman NH. The prevalence of acute respiratory symptoms and role of protective measures among Malaysian Hajj pilg rims. JT ravel Med. 2010;17(2):82-8.

29. Choudhry AJ, Al-Mudaimegh KS, Turkistani AM, Al-Hamdan NA. Hajj-associated acute respiratory infection among hajis from Riyadh. East Mediterr Heal J. 2006;12(34):300-9.

30. Emamian $\mathrm{MH}, \mathrm{Hassani} \mathrm{AM}$, Fateh M. Respiratory tract infections and its preventive measures among Hajj pilgrims, 2010: A nested case control study. Int J Prev Med. 2013;4(9):1030-5.

31. Balaban V, Stauffer WM, Hammad A, Afgarshe M, Abd-Alla M, Ahmed Q, et al. Protective practices and respiratory illness among US travelers to the $2009 \mathrm{Hajj}$. J T ravel Med. 2012;19(3):163-8.

32. Hashim S, Ayub ZN, Mohamed Z, Hasan H, Harun A, Ismail N, et al. The prevalence and preventive measures of the respiratory illness among malaysian pilgrims in 2013 haij season. J Travel Med. 2016;23(2):1-7.

33. Maclntyre CR, Zhang Y, Chughtai AA, Seale H, Zhang D, Chu Y, et al. Cluster randomised controlled trial to examine medical mask use as source control for people with respiratory illness. BMJ Open. 2016;6(12). 
34. Wu J, Xu F, Zhou W, Feikin DR, Lin CY, He X, et al. Risk Factors for SARS among Persons without Known Contact with SARS Patients, Beijing, China. Emerg Infect Dis. $2004 ; 10(2): 210-6$.

35. Cowling BJ, Fung ROP, Cheng CKY, Fang VJ, Chan $\mathrm{KH}$, Seto $\mathrm{WH}$, et al. Preliminary findings of a randomized trial of non-pharmaceutical interventions to prevent influenza transmission in households. PLoS One. 2008;3(5).

36. Cowling, B.J., Chan, K.H., FAng, V.J., Cheng CKY. Facemasks and Hand Hygiene to Prevent Influenza Transmission in Households. Ann Intern Med. 2009;(151):437-46.

37. Aiello AE, Murray GF, Perez V, Coulborn RM, Davis BM, Uddin M, et al. Mask Use, Hand Hygiene, and Seasonal Influenza-Like Illness among Young Adults: A Randomized Intervention Trial. J Infect Dis. 2010;201(4):491-8.

38. Aiello AE, Perez V, Coulborn RM, Davis BM, Uddin M, Monto AS. Facemasks, hand hygiene, and influenza among young adults: A randomized intervention trial. PLoS One. $2012 ; 7(1)$.

39. Larson EL, Ferng Y-H, Wong-McLoughlin J, Wang S, Haber M, Morse SS. Impact of non-pharmaceutical interventions on URIs and influenza in crowded, urban households. Public Health Rep [Internet]. 2010;125(2):178-91. Available from: http://www.embase.com/search/results? subaction=viewrecord\&from=export\&id=L358567046\%5Cnhttp://www.publichealthreport s.org/archives/issueopen.cfm?articleID=2373\%5Cnhttp://sfx.metabib.ch/sfx_locater? sid=EMBASE\&issn=00333549\&id=doi:\&atitle=Impact + of + non-phar 40. Shin K, Wakabayashi H, Sugita C, Yoshida H, Sato K, Sonoda T, et al. Effects of orally administered lactoferrin and lactoperoxidase on symptoms of the common cold. Int J Health Sci (Qassim). 2018;12(5):44-50.

41. Uchida M, Kaneko M, Hidaka Y, Yamamoto H, Honda T, Takeuchi S, et al. Effectiveness of vaccination and wearing masks on seasonal influenza in Matsumoto City, Japan, in the 2014/2015 season: An observational study among all elementary schoolchildren. Prev Med Reports [Internet]. 2017;5:86-91. Available from: http://dx.doi.org/10.1016/j.pmedr.2016.12.002

42. Suess T, Remschmidt C, Schink SB, Schweiger B, Nitsche A, Schroeder K, et al. The role of facemasks and hand hygiene in the prevention of influenza transmission in households: Results from a cluster randomised trial; Berlin, Germany, 2009-2011. BMC Infect Dis. 2012;12:1-16.

43. Canini L, Andréoletti L, Ferrari P, Angelo DR, Blanchon T, Lemaitre M, et al. Surgical mask to prevent influenza transmission in households: A cluster randomized trial. PLoS One. 2010;5(11):1-6.

44. Maclntyre CR, Cauchemez S, Dwyer DE, Seale H, Cheung P, Browne G, et al. Face 
mask use and control of respiratory virus transmission in households. Emerg Infect Dis. 2009;15(2):233-41.

45. Kim CO, Nam CM, Lee DC, Chang J, Lee JW. Is abdominal obesity associated with the 2009 influenza A (H1N1) pandemic in Korean school-aged children? Influenza Other Respi Viruses. 2012;6(5):313-7.

46. Simmerman JM, Suntarattiwong P, Levy J, Jarman RG, Kaewchana S, Gibbons R V., et al. Findings from a household randomized controlled trial of hand washing and face masks to reduce influenza transmission in Bangkok, Thailand. Influenza Other Respi Viruses. 2011;5(4):256-67. 